\title{
The Co-B Amorphous Alloy: A High Capacity Anode Material for an Alkaline Rechargeable Battery
}

\author{
Shujun Qiu, Jianling Huang, Hailiang Chu *, Yongjin Zou, Cuili Xiang, Erhu Yan, Fen Xu \\ and Lixian Sun* \\ Guangxi Key Laboratory of Information Materials, Guangxi Collaborative Innovation Center of Structure and \\ Property for New Energy and Materials, School of Materials Science and Engineering, Guilin University of \\ Electronic Technology, Guilin 541004, China; qiushujun@guet.edu.cn (S.Q.); jianlinghuang@126.com (J.H.); \\ zouy@guet.edu.cn (Y.Z.); xiangcuili@guet.edu.cn (C.X.); yeh@guet.edu.cn (E.Y.); xufen@guet.edu.cn (F.X.) \\ * Correspondence: chuhailiang@guet.edu.cn (H.C.); sunlx@guet.edu.cn (L.S.); \\ Tel.: +86-773-2216607 (H.C. \& L.S.); Fax: +86-773-2290129 (H.C. \& L.S.)
}

Academic Editor: Hugo F. Lopez

Received: 29 August 2016; Accepted: 3 November 2016; Published: 7 November 2016

\begin{abstract}
The Co-B amorphous alloys were prepared via a chemical reduction method by sodium borohydride, using three different cobalt salts $\left(\mathrm{CoCl}_{2} \cdot 6 \mathrm{H}_{2} \mathrm{O}, \mathrm{CoSO}_{4} \cdot 7 \mathrm{H}_{2} \mathrm{O}\right.$, and $\left.\mathrm{Co}\left(\mathrm{NO}_{3}\right)_{2} \cdot 6 \mathrm{H}_{2} \mathrm{O}\right)$ as sources of cobalt. As anode materials in alkaline rechargeable batteries, the Co- $\mathrm{B}$ alloy prepared from $\mathrm{CoCl}_{2} \cdot 6 \mathrm{H}_{2} \mathrm{O}$ has a maximum specific discharge capacity of $844.6 \mathrm{mAh} / \mathrm{g}$, and $306.4 \mathrm{mAh} / \mathrm{g}$ is retained even after 100 cycles at a discharge current of $100 \mathrm{~mA} / \mathrm{g}$. When $\mathrm{Co}\left(\mathrm{NO}_{3}\right)_{2} \cdot 6 \mathrm{H}_{2} \mathrm{O}$ is used as a raw material, the formation of $\mathrm{Co}_{3}\left(\mathrm{BO}_{3}\right)_{2}$ worsens the electrochemical properties of the sample, i.e., a maximum capacity of only $367.0 \mathrm{mAh} / \mathrm{g}$.
\end{abstract}

Keywords: amorphous materials; energy storage and conversion; rechargeable battery; anode

\section{Introduction}

Alkaline secondary batteries are regarded as one of the most promising power sources in the application of modern electronic products. In the past few decades, extensive studies on hydrogen storage alloys (HMs) as anode materials of nickel-metal hydride (Ni-MH) batteries have been reported as being used in portable electronics due to their high specific capacity, good durability, and environmental friendliness [1-6]. Up to now, many kinds of metal hydrides have been developed; for instance, Mg-based alloys exhibit a maximum discharge capacity above $500 \mathrm{mAh} / \mathrm{g}$, but the poor cycling ability limits widespread practical application [7]. Comparatively, the $\mathrm{AB}_{5}$-type $\mathrm{MHs}$ widely used as commercialized anode materials for $\mathrm{Ni}-\mathrm{MH}$ secondary batteries usually have a reversible discharge capacity of about $310 \mathrm{mAh} / \mathrm{g}$ [8].

Recently, a new class of anode materials based on transition metals that possess superior electrochemical properties was developed [9-11]. For instance, ultra-fine particles of the $\mathrm{Co}-\mathrm{B}$ amorphous alloy were successfully prepared through $\mathrm{NaBH}_{4}$ reduction of $\mathrm{CoSO}_{4}$. As an anode in an alkaline rechargeable battery, the discharge capacity of more than $600 \mathrm{mAh} / \mathrm{g}$ is obtained at the initial cycle. In addition, the cycling ability and high rate capability are fairly good [9]. The FeB alloy prepared with an electric arc method achieved an excellent reversible capacity of $312 \mathrm{mAh} / \mathrm{g}$ as well as good cyclability [11]. In fact, the electrochemical reaction is based on the multi-electron redox reaction [12]. For instance, Co-based alloys as anodes in alkaline secondary batteries are primarily ascribed to the redox between $\mathrm{Co}$ and $\mathrm{Co}(\mathrm{OH})_{2}$ [13-19]. Wang et al. first reported that the Co-B alloy prepared via a chemical reduction method in an aqueous solution from bivalent cobalt sulfate has a reversible discharge capacity exceeding $300 \mathrm{mAh} / \mathrm{g}$ at $100 \mathrm{~mA} / \mathrm{g}$ in an aqueous $\mathrm{KOH}$ solution [9], very close to those of conventional hydrogen storage alloys. Using cobalt acetate as raw 
material, Tong et al. prepared a Co-B alloy in water/cetyl-trimethyl-ammonium bromide/n-hexanol microemulsion, which has a maximum discharge capacity of $357 \mathrm{mAh} / \mathrm{g}$ and still has $347 \mathrm{mAh} / \mathrm{g}$ after 50 cycles [20]. Via the vacuum freeze-drying method from bivalent cobalt chloride, the as-prepared Co-B alloy has a maximum discharge capacity of $438 \mathrm{mAh} / \mathrm{g}$ [21]. In a very recent study, an amorphous Co-B alloy prepared by the reduction of $\mathrm{CoSO}_{4}$ with $\mathrm{KBH}_{4}$ was found to have an extremely high discharge capacity of $968.6 \mathrm{mAh} / \mathrm{g}$, and the introduction of $\mathrm{NaS}_{2} \mathrm{O}_{3}$ into the alkaline electrolyte was found to be helpful for long-term battery storage [22]. Among previous reports, almost all of the Co-B alloys prepared through chemical reduction have an amorphous structure in nature, but there is a huge difference in the electrochemical performance. Moreover, the anions in the cobalt salts have an unclear effect on the particle size, morphology, properties, etc. This has been confirmed by the difference in the Co-B alloys' catalytic activity using different cobalt salts in hydrogen production by hydrolysis of metal borohydrides [23].

In order to understand the effect of anions on the electrochemical performance, the Co- $\mathrm{B}$ alloys were prepared via the reduction of cobalt chloride hexahydrate $\left(\mathrm{CoCl}_{2} \cdot 6 \mathrm{H}_{2} \mathrm{O}\right)$, cobalt sulfate heptahydrate $\left(\mathrm{CoSO}_{4} \cdot 7 \mathrm{H}_{2} \mathrm{O}\right)$, and cobalt nitrate hexahydrate $\left(\mathrm{Co}\left(\mathrm{NO}_{3}\right)_{2} \cdot 6 \mathrm{H}_{2} \mathrm{O}\right)$ with sodium borohydride, and the effect of the anions on the electrochemical performance was investigated.

\section{Materials and Methods}

\subsection{Sample Preparation}

The experimental procedure for sample preparation is described in the literature [10]. Typically, cobalt salt, i.e., cobalt chloride hexahydrate, cobalt sulfate heptahydrate, and cobalt nitrate hexahydrate, was first introduced into a round-bottom flask, which contains $60 \mathrm{~mL}$ of deionized water. Subsequently, $15 \mathrm{~mL}$ of freshly prepared $200 \mathrm{~g} / \mathrm{L} \mathrm{NaBH}_{4}$ solution was pumped into the aforementioned solution under moderate stirring. Then, the black precipitate was filtrated after no bubble generation, and washed with deionized water and absolute ethanol. Finally, the samples were vacuumed at $60{ }^{\circ} \mathrm{C}$ for $8 \mathrm{~h}$ to remove water and ethanol. The sample was named as $\mathrm{S}_{\mathrm{C}}, \mathrm{S}_{\mathrm{S}}$, and $\mathrm{S}_{\mathrm{N}}$ according to the used salt, i.e., chloride, sulfate, and nitrate, respectively.

\subsection{Structural and Morphological Characterization}

The crystal structure and surface morphology of the samples were characterized by a PANalytical X-ray Diffractometer (XRD, X'Pert MPD PRO, Co K $\alpha, 45 \mathrm{kV} \times 40 \mathrm{~mA}$, Eindhoven, The Netherland) and scanning electron microscopy (SEM, QUANTA FEG450, $10 \mathrm{kV}$, Eindhoven, The Netherland). The bulk elemental composition of $\mathrm{Co}$ and $\mathrm{B}$ in the as-prepared sample was measured via inductive coupled plasma atomic emission spectroscopy (ICP-AES, Optima 8000, PerkinElmer, Waltham, MA, USA). The specific surface area $\left(S_{\mathrm{BET}}\right)$ was measured via nitrogen absorption at $77 \mathrm{~K}$ after degassing at $373 \mathrm{~K}$ for $4 \mathrm{~h}$ (QUANTACHROME AUTOSORB IQ2, Boynton Beach, FL, USA).

\subsection{Electrochemical Measurements}

The anode was fabricated by pressing a mixture of the Co-B alloy powder and nickel powder in a weight ratio of 1:3 into a circular pellet of $ø 10 \mathrm{~mm}$ under $25 \mathrm{MPa}$ pressure. Electrochemical measurements were conducted in a tri-electrode cell containing a counter electrode $\left(\mathrm{Ni}(\mathrm{OH})_{2} / \mathrm{NiOOH}\right)$ and a reference electrode $(\mathrm{Hg} / \mathrm{HgO})$, and a $6 \mathrm{M} \mathrm{KOH}$ solution as the electrolyte. The charge-discharge performance was evaluated with a LAND-CT2001A battery system (Wuhan, China). In each cycle test, the anode was charged for $3 \mathrm{~h}$ at a constant current density of $300 \mathrm{~mA} / \mathrm{g}$, rested for $5 \mathrm{~min}$, and discharged to $-0.6 \mathrm{~V}$ (versus $\mathrm{Hg} / \mathrm{HgO}$ ) at a constant current density of $100 \mathrm{~mA} / \mathrm{g}$.

The cyclic voltammetry (CV) curves, electrochemical impedance spectroscopy (EIS), and linear polarization (LP) curves of the Co-B alloys were recorded on a Zahner IM6e electrochemical workstation (Zahner-Electrik, Germany). LP was measured by scanning the anode potential at a rate of $0.1 \mathrm{mV} / \mathrm{s}$ from -5 to $5 \mathrm{mV}$ (versus open circuit potential). EIS was conducted from $10 \mathrm{kHz}$ to $5 \mathrm{mHz}$ with 
an amplitude of $5 \mathrm{mV}$ (versus open circuit potential). The scanning rate of CV curves was $0.5,1$, and $5 \mathrm{mV} / \mathrm{s}$, and the potential range was from -1.2 to $-0.4 \mathrm{~V}$ (versus $\mathrm{Hg} / \mathrm{HgO}$ ). The EIS and LP curves were measured at a 50\% depth of discharge (DOD).

\section{Results and Discussion}

Analyzed through ICP-AES technique, the chemical composition of the samples was found to be $\mathrm{CoB}_{0.50}, \mathrm{CoB}_{0.54}$, and $\mathrm{CoB}_{0.36}$ for $\mathrm{S}_{\mathrm{C}}, \mathrm{S}_{\mathrm{S}}$, and $\mathrm{S}_{\mathrm{N}}$, respectively. The following reactions were suggested to form the Co-B alloys [24]:

$$
\begin{gathered}
\mathrm{BH}_{4}{ }^{-}+2 \mathrm{H}_{2} \mathrm{O} \rightarrow \mathrm{BO}_{2}^{-}+4 \mathrm{H}_{2} \\
2 \mathrm{Co}^{2+}+\mathrm{BH}_{4}^{-}+2 \mathrm{H}_{2} \mathrm{O} \rightarrow 2 \mathrm{Co}+\mathrm{BO}_{2}^{-}+4 \mathrm{H}^{+}+2 \mathrm{H}_{2} \\
\mathrm{BH}_{4}{ }^{-}+\mathrm{H}_{2} \mathrm{O} \rightarrow \mathrm{B}+\mathrm{OH}^{-}+2.5 \mathrm{H}_{2}
\end{gathered}
$$

Figure 1A shows XRD patterns of as-prepared Co-B alloys. There is a very broad diffraction peak appearing at $2 \theta=45^{\circ}-60^{\circ}$ with very minor peaks observed at $43^{\circ}$, indicating that the main phase is an amorphous structure in nature as reported in $[9,19,22]$. As for the sample $S_{N}$, it mainly shows an amorphous phase, except for two diffraction peaks at about 40 and $72^{\circ}$, matching the strongest (121) and moderately strong (330) diffraction peaks of the orthorhombic $\mathrm{Co}_{3}\left(\mathrm{BO}_{3}\right)_{2}$ observed [25]. SEM images (shown in Figure $1 B$ ) show that both $S_{C}$ and $S_{S}$ consist of very small primary particles in a few tens of nanometers with good uniform distribution, while $S_{N}$ shows a much larger aggregated block (secondary particle) on a much larger scale. This highlights that the anions in the precursors have an important influence on the sample morphology and thus give rise to a distinct difference in the electrochemical properties. The specific surface area of the powders was determined by the BET method. The as-prepared $S_{C}$ and $S_{S}$ have a surface area of 26.3 and $22.5 \mathrm{~m}^{2} / \mathrm{g}$. Due to the formation of $\mathrm{Co}_{3}\left(\mathrm{BO}_{3}\right)_{2}$ for $\mathrm{S}_{\mathrm{N}}$, it has a high value of $169.0 \mathrm{~m}^{2} / \mathrm{g}$, which is similar to the result of $(\mathrm{Ni}, \mathrm{Co})_{3}\left(\mathrm{BO}_{3}\right)_{2}[26]$. XPS results of $\mathrm{S}_{\mathrm{S}}$ show that the B element is in the oxidized state and the Co element exists in both elemental and oxidized states [27]. This means that the surface of the Co-B sample consists of $\mathrm{Co}, \mathrm{CoO}$, and $\mathrm{B}_{2} \mathrm{O}_{3}$, which was also reported in [22]. Due to the severe agglomeration, the secondary particle size $\left(D_{50}\right)$ of the samples was determined to be $0.8,1.2$, and $3.3 \mu \mathrm{m}$ for $S_{C}, S_{S}$, and $S_{N}$, respectively.

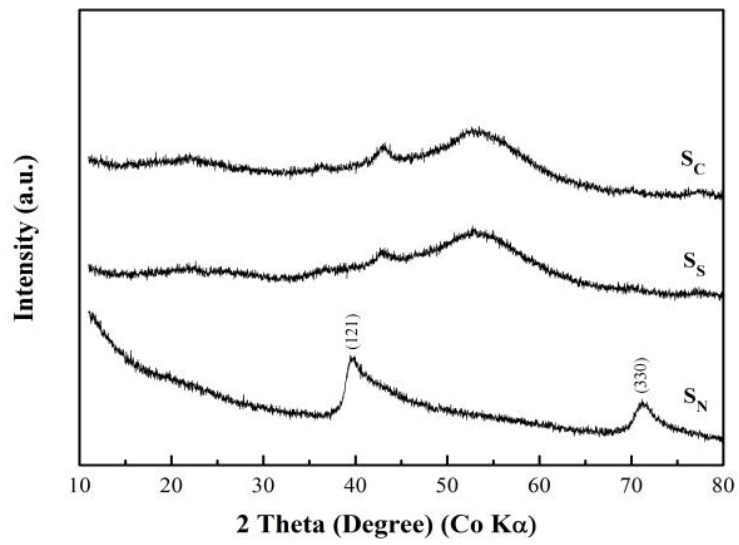

(A)

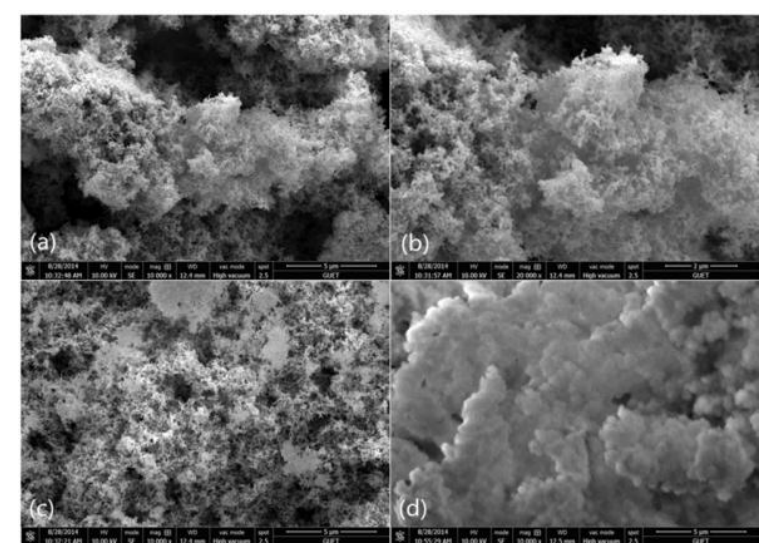

(B)

Figure 1. (A) XRD patterns and (B) SEM micrographs of the as-prepared Co-B alloys: (a) and (b) for $\mathrm{S}_{\mathrm{C}}$ at different magnifications; (c) for $\mathrm{S}_{\mathrm{S}}$; and (d) for $\mathrm{S}_{\mathrm{N}}$.

The cycle stability of the Co-B anodes tested at $298 \mathrm{~K}$ is shown in Figure 2. Generally, most of anodes made from hydrogen storage alloys need several charge-discharge cycles to reach the maximum of discharge capacity (the so-called activation). In comparison, Co-B alloys show such an excellent electrochemical activity that all of them achieve their maximum discharge capacities at the initial cycle. 
The inset gives the maximum discharge capacity of Co-B alloys at $298 \mathrm{~K}$. Obviously, the anions in the different cobalt salts observably affect the microstructure and then the electrochemical properties. For example, $\mathrm{S}_{\mathrm{C}}$ has an extremely high maximum discharge capacity of $844.6 \mathrm{mAh} / \mathrm{g}$, which is much higher than that of conventional hydrogen storage alloys [1-6]. The maximum discharge capacity of $S_{S}$ and $S_{N}$ are 669.8 and $367.0 \mathrm{mAh} / \mathrm{g}$, respectively. However, the capacity decays rapidly in the first few cycles for $S_{S}$ an $S_{C}$ due to the irreversible hydrogen desorption reaction [22]. Subsequently, the reversible capacity is almost retained at a constant in 40 charge-discharge cycles. It is worth noting that $\mathrm{S}_{\mathrm{C}}$ is retained at about $440 \mathrm{mAh} / \mathrm{g}$, even after 40 cycles. The discharge capacity of $\mathrm{S}_{\mathrm{C}}$ and $\mathrm{S}_{\mathrm{N}}$ is $306.4 \mathrm{mAh} / \mathrm{g}$ and $187.6 \mathrm{mAh} / \mathrm{g}$ at the 100th charge-discharge cycle, respectively, and it is $287.2 \mathrm{mAh} / \mathrm{g}$ for $\mathrm{S}_{\mathrm{S}}$ at the 92th cycle. As a comparison, the discharge capacity of $\mathrm{MnO}_{2}$ as the cathode in the $\mathrm{KOH}$ electrolyte is only 330 and $60 \mathrm{mAh} / \mathrm{g}$ for the 1st and 2nd cycles. The redox mechanism studied using transmission electron microscopy (TEM, JEOL 2010F, Tokyo, Japan) and its associated techniques involves a $\mathrm{K}^{+}$ion insertion-surface film formation on the host framework structure of $\mathrm{MnO}_{2}$ [28], and this process is not fully reversible, responsible for the sharp decrease of the discharge capacity. This mechanism is very different from that in our case, discussed in the following parts.

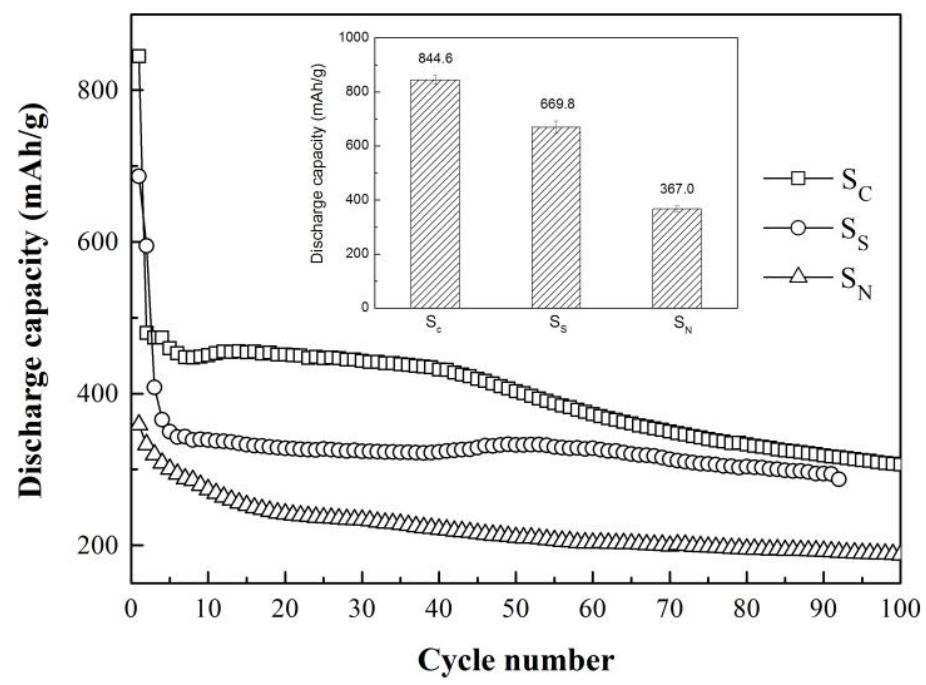

Figure 2. Cycling life of Co-B alloys as the anodes. The inset shows the maximum discharge capacity.

Figure 3 shows the charge-discharge curves of the Co-B alloy anodes at the 15th and 35th cycles. All charge curves have two plateaus in the potential range of $0.88-1.1 \mathrm{~V}$ (versus $\mathrm{Hg} / \mathrm{HgO}$ ), while one flat discharge plateau is observed for each $\mathrm{Co}-\mathrm{B}$ anode. $\mathrm{S}_{\mathrm{C}}$ has a much higher discharge plateau appearing at $\sim 0.8 \mathrm{~V}$ (versus $\mathrm{Hg} / \mathrm{HgO}$ ). Moreover, it has almost the same discharge plateau between the 15th and 35th cycles, which indicates that an excellent reversible electrochemical reaction of $\mathrm{S}_{\mathrm{C}}$. In the case of $S_{S}$ and $S_{N}$, the increase of hysteresis between charge and discharge voltage plateaus indicates a severe polarization of the alloy electrode, which probably results in the deterioration of electrochemical properties. 


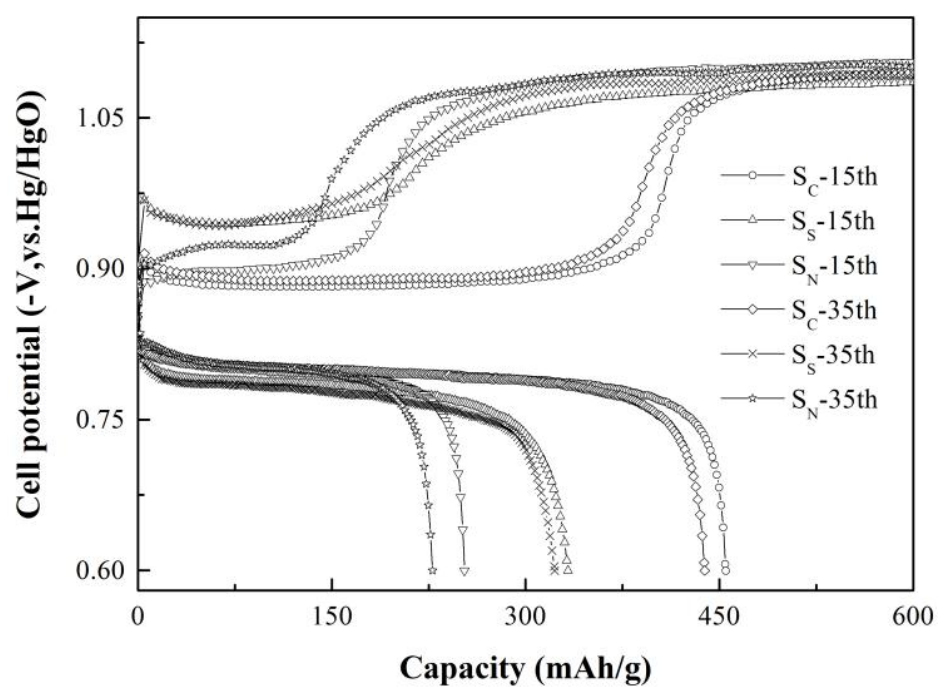

Figure 3. Potential-capacity curves of Co-B alloy anodes at the 15th and 35th cycles.

According to the above experimental results, it can be concluded that the electrochemical performance is in following order: $\mathrm{S}_{\mathrm{C}}>\mathrm{S}_{\mathrm{S}}>\mathrm{S}_{\mathrm{N}}$. As is well-known, $\mathrm{Cl}$ is the most electronegative element among the three anions, so $\mathrm{Co}^{2+}$ is more electrophilic in $\mathrm{CoCl}_{2}$ and attracts $\mathrm{BH}_{4}{ }^{-}$, which results in an improved electrochemical performance [29]. During the synthesis of Co-B alloys, it was confirmed that the anion plays a crucial role in altering the reaction pathways for the formation of $\mathrm{Co}-\mathrm{B}$ or $\mathrm{Co}(\mathrm{OH})_{2}$ [30]. Generally, once a cobalt salt solution is mixed with a $\mathrm{NaBH}_{4}$ solution, $\mathrm{Co}(\mathrm{OH})_{2}$ is first formed and then transforms into Co-B alloys. However, in the case of $\mathrm{Co}\left(\mathrm{NO}_{3}\right)_{2} \cdot 6 \mathrm{H}_{2} \mathrm{O}$ as the cobalt source, $\mathrm{Co}_{3}\left(\mathrm{BO}_{3}\right)_{2}$ as a by-product was obtained during the formation of the $\mathrm{Co}-\mathrm{B}$ alloy. Moreover, $\mathrm{NO}_{3}{ }^{-}$has a negative effect on the formation of the Co-B alloy and thus results in the aggregation of $\mathrm{Co}(\mathrm{OH})_{2}$ powder, which therefore leads to the morphology with many aggregated particles as shown in Figure 1B. However, the formation of $\mathrm{Co}(\mathrm{OH})_{2}$ layer hampers the charge transfer at the particle surface and thus may decline the electrochemical activity of the Co-B alloy. In addition, the electrochemical performance of Co-B alloys as anodes is also dependent on their particle size. The smaller the particle size, the higher the electrochemical activity [20]. Compared with $S_{N}$, the particle size of $S_{C}$ is much smaller (Figure 1B), which may be partially responsible for the improvement of electrochemical properties. Thus, $\mathrm{S}_{C}$ has the highest reversible discharge capacity, and $\mathrm{S}_{\mathrm{N}}$ has the lowest capacity in this work. The difference between $S_{N}$ and $S_{S}$ may be due to the difference in particle size, surface area, or both.

The electrochemical reaction mechanism was investigated via cyclic voltammetry (CV), electrochemical impedance spectroscopy (EIS), and linear polarization (LP), shown in Figure 4. In the $\mathrm{CV}$ curves, a remarkable oxidation peak appears at $-0.73 \mathrm{~V}$ (versus $\mathrm{Hg} / \mathrm{HgO}$ ) and a strong reduction peak appears at $-0.99 \mathrm{~V}$ (versus $\mathrm{Hg} / \mathrm{HgO}$ ) at a scanning rate of $0.5 \mathrm{mV} / \mathrm{s}$. This pair of redox peaks suggests a reversible electrochemical reaction occurring on the $\mathrm{S}_{C}$ anode. The charge-transfer reaction resistance $R_{\mathrm{ct}}$ on the anode surface determined from the EIS data by an equivalent circuit proposed by Kuriyama et al. [31] shows that, among the studied Co-B alloys, a low value of $201.4 \mathrm{~m} \Omega$ is obtained for $S_{C}$, while a high value of $264.1 \mathrm{~m} \Omega$ for $S_{N}$ is probably due to the formation of the $\mathrm{Co}(\mathrm{OH})_{2}$ layer. Moreover, the exchange current density $I_{0}$ of $S_{C}, S_{S}$, and $S_{N}$ obtained from linear polarization is 122.6, 32.6 , and $18.9 \mathrm{~mA} / \mathrm{g}$, respectively, which agrees well with EIS results. Through the CV, EIS, and LP measurements, it can be safely inferred that $\mathrm{S}_{C}$ has much better electrochemical kinetics among the three samples. 

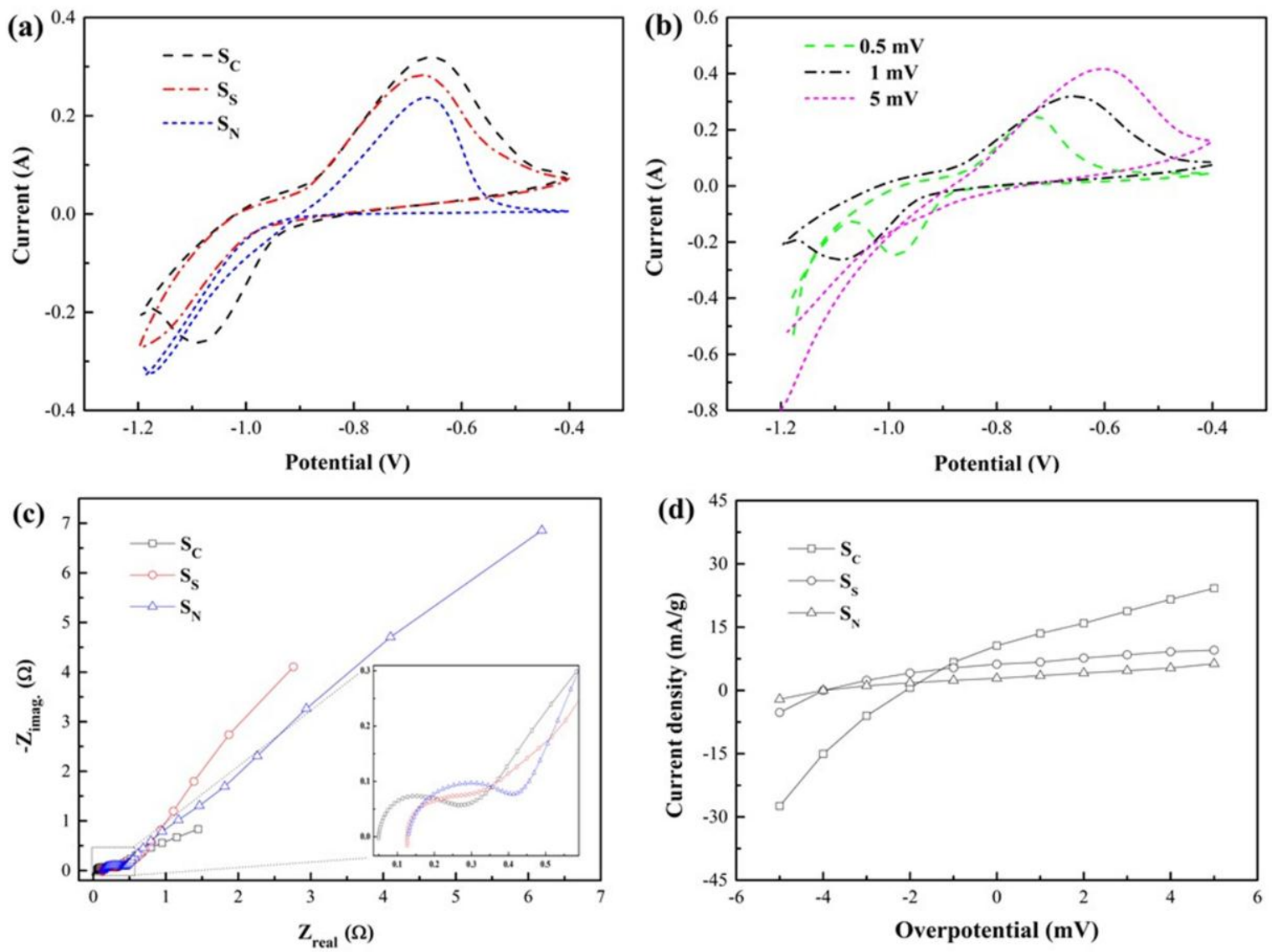

Figure 4. Typical CV curves of Co-B alloys: (a) the scanning rate was $1 \mathrm{mV} / \mathrm{s}$; (b) the CV curves of the $\mathrm{S}_{\mathrm{C}}$ at different scanning rates; (c) EIS and (d) LP of Co-B alloy electrodes at 50\% DOD and $298 \mathrm{~K}$.

\section{Conclusions}

Co-B alloys with high discharge capacity were successfully prepared via a chemical reduction method from cobalt chloride hexahydrate, cobalt sulfate heptahydrate, and cobalt nitrate hexahydrate. The structural features, the electrochemical performance, and the electrochemical reaction mechanism were systematically investigated. XRD and SEM show that Co-B alloys are at the nanoscale with uniform nanoparticles. All the anodes achieve maximum discharge capacities at the initial cycle, and the maximum discharge capacity of $\mathrm{S}_{\mathrm{C}}, \mathrm{S}_{\mathrm{S}}$, and $\mathrm{S}_{\mathrm{N}}$ was $844.6,669.8$, and $367.0 \mathrm{mAh} / \mathrm{g}$, respectively. The discharge capacity of $\mathrm{S}_{\mathrm{C}}$ is retained at $431.8 \mathrm{mAh} / \mathrm{g}$, even after 40 charge/discharge cycles. The experimental results obtained in this work indicate that the Co-B alloy prepared from cobalt chloride hexahydrate is one of the most promising candidates for practical applications in alkaline secondary batteries.

Acknowledgments: This research was financially supported by the National Natural Science Foundation of China (51361006, 51401059, 51461010, 51361005, 51371060, U1501242, and 51461011) and the Guangxi Natural Science Foundation (2014GXNSFAA118043, 2015GXNSFBA139208 and 2014GXNSFAA118333).

Author Contributions: H.C., F.X., and L.S. conceived and designed the experiments; S.Q., J.H., and C.X. performed the experiments; S.Q., Y.Z., and H.C. analyzed the data; S.Q., J.H., and E.Y. contributed reagents/materials/analysis tools; S.Q. and H.C. wrote the paper.

Conflicts of Interest: The authors declare no conflict of interest. 


\section{References}

1. Tliha, M.; Khaldi, C.; Boussami, S.; Fenineche, N.; El-Kedim, O.; Mathlouthi, H.; Lamloumi, J. Kinetic and thermodynamic studies of hydrogen storage alloys as negative electrode materials for $\mathrm{Ni} / \mathrm{MH}$ batteries: A review. J. Solid State Electrochem. 2014, 18, 577-593. [CrossRef]

2. Huang, J.L.; Qiu, S.J.; Chu, H.L.; Zou, Y.J.; Xiang, C.L.; Zhang, H.Z.; Xu, F.; Sun, L.X.; Ouyang, L.Z.; Zhou, H.Y. Enhancement of the electrochemical properties of rare earth-based alloy by doping with CoZnB alloy. Int. J. Hydrog. Energy 2015, 40, 14173-14178. [CrossRef]

3. Liu, Y.F.; Pan, H.G.; Gao, M.X.; Wang, Q.D. Advanced hydrogen storage alloys for Ni/MH rechargeable batteries. J. Mater. Chem. 2011, 21, 4743-4755. [CrossRef]

4. Qiu, S.J.; Huang, J.L.; Chu, H.L.; Zou, Y.J.; Xiang, C.L.; Zhang, H.Z.; Xu, F.; Sun, L.X.; Zhou, H.Y. Influence of boron introduction on structure and electrochemical hydrogen storage properties of Ti-V-based alloys. J. Alloy. Compd. 2015, 648, 320-325. [CrossRef]

5. Zhao, X.Y.; Li, J.J.; Yao, Y.; Ma, L.Q.; Shen, X.D. Electrochemical hydrogen storage properties of a non-equilibrium $\mathrm{Ti}_{2} \mathrm{Ni}$ alloy. RSC Adv. 2012, 2, 2149-2153. [CrossRef]

6. Qiu, S.J.; Huang, J.L.; Chu, H.L.; Zou, Y.J.; Xiang, C.L.; Zhang, H.Z.; Xu, F.; Sun, L.X.; Ouyang, L.Z.; Zhou, H.Y. Influence of $\mathrm{Zr}$ addition on structure and performance of rare earth $\mathrm{Mg}$-based alloys as anodes in $\mathrm{Ni} / \mathrm{MH}$ battery. Metals 2015, 5, 565-577. [CrossRef]

7. Zhuang, X.Y.; Zhang, Y.; Zhu, Y.F.; Qu, Y.; Zhan, L.Y.; Wan, N.; Cheng, H.H.; Guo, X.L.; Chen, J.; Wang, Z.M.; et al. The effects of $\mathrm{Pd}$ and/or $\mathrm{Zr}$ additives on the structures and cyclic stabilities of $\mathrm{Mg}_{50} \mathrm{Ni}_{50}$-based electrode alloys. Int. J. Hydrog. Energy 2015, 40, 2768-2774. [CrossRef]

8. Dymek, M.; Bala, H.; Hackemer, A.; Drulis, H. Hydrogenation and electrochemical corrosion properties of $\mathrm{LaNi}_{4.5} \mathrm{Co}_{0.5}$ alloy doped with aluminum. Solid State Ionics 2015, 271, 116-120. [CrossRef]

9. Wang, Y.D.; Ai, X.P.; Yang, H.X. Electrochemical hydrogen storage behaviors of ultrafine amorphous Co-B alloy particles. Chem. Mater. 2004, 16, 5194-5197. [CrossRef]

10. Qiu, S.J.; Huang, J.L.; Shen, F.H.; Pang, R.; Chu, H.L.; Zou, Y.J.; Xiang, C.L.; Xu, F.; Du, Y.; Wang, J.C.; et al. Ternary Co-Ni-B amorphous alloy with a superior electrochemical performance in a wide temperature range. Int. J. Hydrog. Energy 2016, 41, 3955-3960. [CrossRef]

11. Qiu, S.J.; Huang, J.L.; Shen, F.H.; Pang, R.; Chu, H.L.; Zou, Y.J.; Xiang, C.L.; Yan, E.H.; Xu, F.; Sun, L.X.; et al. Enhancement of the electrochemical performance of $\mathrm{CoB}$ amorphous alloy through the addition of $\mathrm{A}_{2} \mathrm{~B}_{7}$-type alloy. Int. J. Hydrog. Energy 2016, 41, 16142-16147.

12. Gao, X.P.; Yang, H.X. Multi-electron reaction materials for high energy density batteries. Energy Environ. Sci. 2010, 3, 174-189.

13. Zhao, X.Y.; Ma, L.Q.; Yao, Y.; Yang, M.; Ding, Y.; Shen, X.D. Electrochemical energy storage of Co powders in alkaline electrolyte. Electrochim. Acta 2010, 55, 1169-1174. [CrossRef]

14. He, G.H.; Jiao, L.F.; Yuan, H.T.; Zhang, Y.Y.; Zhang, Y.H.; Wang, Y.J. Effect of synthesis method on the structure and electrochemical behaviour of Co-Si particles. Int. J. Hydrog. Energy 2007, 32, 3416-3419. [CrossRef]

15. Lu, D.S.; Li, W.S.; Xiao, F.M.; Tang, R.H. Drastically enhanced cycle life of Co-B alloy electrode by 8-hydroxyquinoline at elevated temperature. Electrochem. Commun. 2010, 12, 362-366. [CrossRef]

16. Wang, Q.H.; Jiao, L.F.; Du, H.M.; Huan, Q.N.; Peng, W.X.; Song, D.W.; Wang, Y.J.; Yuan, H.T. Chainlike structures assembled by Co hierarchitectures: Synthesis and electrochemical properties as negative materials for alkaline secondary batteries. J. Mater. Chem. 2011, 21, 14159-14162. [CrossRef]

17. Wang, Q.H.; Jiao, L.F.; Du, H.M.; Huan, Q.N.; Peng, W.X.; Song, D.W.; Wang, Y.J.; Yuan, H.T. Novel flower-like CoS hierarchitectures: One-pot synthesis and electrochemical properties. J. Mater. Chem. 2011, 21, 327-329. [CrossRef]

18. Cao, Y.L.; Zhou, W.C.; Li, X.Y.; Ai, X.P.; Gao, Y.P.; Yang, H.X. Electrochemical hydrogen storage behaviors of ultrafine Co-P particles prepared by direct ball-milling method. Electrochim. Acta 2006, 51, 4285-4290. [CrossRef]

19. Lu, D.S.; Li, W.S.; Tan, C.L.; Zeng, R.H. Investigation of Co-B-S system as anode material for secondary alkaline battery. Electrochim. Acta 2009, 55, 171-177. [CrossRef] 
20. Tong, D.G.; Wang, D.; Chu, W.; Sun, J.H.; Wu, P. Cobalt-boron amorphous alloy prepared in water/cetyl-trimethyl-ammonium bromide/ $n$-hexanol microemulsion as anode for alkaline secondary batteries. Electrochim. Acta 2010, 55, 2299-2305. [CrossRef]

21. Wu, C.; Pang, C.H.; Wu, F.; Bai, Y.; Chen, C.; Zhong, Y. Effects of the pre-freezing time on the structures and electrochemical performances of Co-B alloys. Adv. Mater. Res. 2012, 391, 1085-1089. [CrossRef]

22. Zhao, X.Y.; Li, J.J.; Yao, Y.; Ma, L.Q.; Shen, X.D. Electrochemical redox mechanism of Co-B-H anode material and its optimization by a novel electrolyte additive. RSC Adv. 2013, 3, 1327-1331. [CrossRef]

23. Patel, N.; Miotello, A. Progress in Co-B related catalyst for hydrogen production by hydrolysis of boron-hydrides: A review and the perspectives to substitute noble metals. Int. J. Hydrog. Energy 2015, 40, 1429-1464. [CrossRef]

24. Chen, Y. Chemical preparation and characterization of metal-metalloid ultrafine amorphous alloy particles. Catal. Today 1998, 44, 3-16. [CrossRef]

25. Zhang, X.X.; Gu, G.; Huang, H.J.; Yang, S.H.; Du, Y.W. Self-assembled $\mathrm{Co}_{3}\left(\mathrm{BO}_{3}\right)_{2} /$ surfactant nanostructured multilayers. J. Phys. Condens. Matter 2001, 13, 3913. [CrossRef]

26. Chen, Y.Z.; Liu, Y.N.; Yan, W. Preparation of porous $(\mathrm{Ni}, \mathrm{Co})_{3}\left(\mathrm{BO}_{3}\right)_{2} / \mathrm{Ni}(\mathrm{OH})_{2}$ nanosheet networks as pseudocapacitor materials with superior performance. J. Mater. Chem. A 2014, 2, 5903-5909. [CrossRef]

27. Zou, Y.J.; Cheng, J.; Wang, Q.Y.; Xiang, C.L.; Chu, H.L.; Qiu, S.J.; Zhang, H.Z.; Xu, F.; Liu, S.S.; Tang, C.Y.; et al. Cobalt-boron/nickel-boron nanocomposite with improved catalytic performance for the hydrolysis of ammonia borane. Int. J. Hydrog. Energy 2015, 40, 13423-13430. [CrossRef]

28. Minakshi, M. Examining manganese dioxide electrode in $\mathrm{KOH}$ electrolyte using TEM technique. J. Electroanal. Chem. 2008, 616, 99-106. [CrossRef]

29. Akdim, O.; Demirci, U.B.; Muller, D.; Miele, P. Cobalt (II) salts, performing materials for generating hydrogen from sodium borohydride. Int. J. Hydrog. Energy 2009, 34, 2631-2637. [CrossRef]

30. Wu, C.; Bai, Y.; Wu, F.; Yi, B.L.; Zhang, H.M. Highly active cobalt-based catalysts in situ prepared from CoX $\mathrm{X}_{2}$ $\left(\mathrm{X}=\mathrm{Cl}^{-}, \mathrm{NO}_{3}{ }^{-}\right)$and used for promoting hydrogen generation from $\mathrm{NaBH}_{4}$ solution. Int. J. Hydrog. Energy 2010, 35, 2675-2679. [CrossRef]

31. Kuriyama, N.; Sakai, T.; Miyamura, H.; Uehara, I.; Ishikawa, H.; Iwasaki, T. Electrochemical impedance and deterioration behavior of metal hydride electrodes. J. Alloy. Compd. 1993, 202, 183-197. [CrossRef]

(C) 2016 by the authors; licensee MDPI, Basel, Switzerland. This article is an open access article distributed under the terms and conditions of the Creative Commons Attribution (CC-BY) license (http://creativecommons.org/licenses/by/4.0/). 